UDC 339.138

JEL Classification M15; M31

\author{
Chaikovska Maryna \\ Phd., Associate Professor \\ Department of Marketing and Business Administration
}

Shkeda Oleksandr

Ph. D student, Lecturer

Odessa I.I.Mechnikov National University

(Odesa, Ukraine)

\title{
REENGINEERING BRAND COMMUNICATION WITH THE CONSUMER BY INTEGRATING POP-CULTURAL INFLUENCER MARKETING TOOLS INTO TRADITIONAL MARKETING COMPONENTS
}

The article is devoted to the processes of marketing communications in the context of informatization and digitalization of society. The problem of oversaturation of information platforms with content is considered. As a solution, it was proposed to use influencer marketing tools with integrated manifestations of the pop culture. The informational prerequisites for the use of this approach are revealed. The transformation of the marketing-mix components is described, as well as examples and cases of using the proposed method for solving the existing problem for each of the components are presented. The principles of integrating pop-cultural influencer marketing tools for each of the marketing mix components are formulated. The relevance of the reengineering of brand communications with the consumer by integrating pop-cultural influencer marketing tools into the components of traditional marketing is determined.

Key words: marketing management, integrated marketing communication, brand building, reengineering, influencer marketing, 4P, 7P, informatization, digitalization, pop-culture

\section{DOI: 10.15276/mdt.5.32.2021.6}

Statement of the problem in general form and it's connection with important scientific or practical tasks. One of the consequences of the processes of informatization and digitalization of modern society is the state of a fierce struggle between brands for the consumers' attention. Traditional marketing or public relations tools are losing their effectiveness in terms of communicative function. The absence of consumers desire to spend time viewing commercial content, as well as the availability of informational tools (spam folder in e-mail services, advertisement blocker in the browser, etc.) lead to the issue of reengineering communicative tools and communicative channels between brand and consumer. The primary goal of marketing, which is to influence consumer behavior, today is complicated by the need at first to break through the exponentially increasing flow of information. The obvious solution to add weight to a brand's voice is to use influencer marketing techniques, which in turn continue to exist as dynamic and at the state of permanent evolving. A non-obvious solution would be to transform communicative channels that correspond to current market trends and user habits in the context of traditional operational marketing, namely the marketing-mix components.

(C) 2021 The Authors. This is an open access article under the CC BY license (http://creativecommons.org/licenses/by/4.0) 
One of the variable solutions to this issue in the context of modern consumer habits, which we think is the most optimal, will be the use of pop-cultural manifestations in influencer marketing methods.

Analysis of the latest research and publications, which initiated the solution of this problem on which the author relies. The problem of integrating the pop culture into marketing activities remains poorly understood, which looks absolutely paradoxical, taking into consideration the fact of prevalence of the practical application of this method. In the course of writing the article, works on the influence of the pop culture on a person and society in general (D.I. Selivanova, I.F. Petrov, Y.P. Drabchuk), research in influencer marketing (Carsten Schwemmer, Daniel Carter) and works directly affecting the connection between the pop culture and enterprise marketing (Sophie Bishop, G.L. Tulchinsky, Y.S. Gritsyuk, O.I. Popova) were analyzed [1-9].

The works [1-3] explain the importance of the popular culture, it's manifestation in society and communications. They also describe the characteristics of the influence of the pop culture on the opinion of the masses, but do not consider this process from the point of view of revealing the marketing potential.

The author's works are devoted to the development of influencer marketing tools as a response to changing social attitudes in society. The interaction of marketing and society values is expressed in social movements based on social problems, but the issue of the influence of pop-cultural manifestations in this interaction is not disclosed [4-5].

The paper [6] describes the usefulness of opinion leaders in the use of influencer marketing tools in social networks. The main advantage of the work we would like to note the introduction of the term "hustle", distinguishing the difference between traditional opinion leaders and those who are more close to the pop culture.

Works with the mention the possibility of using the pop culture in the framework of the current marketing strategy [7-10] focus on the cultural component of the manifestations of mass culture, and also do not offer specific models or methodologies for using the pop culture in influencer marketing strategies.

Highlighting the previously unresolved parts of the general problem to which the article is devoted. Insofar as the solution to the problem is located at the intersection of knowledge from different fields, there is no unitary theoretical justification for the use of the pop culture in the marketing communications management system. The ideas presented in existing scientific papers will serve as a starting point for our research.

Formulation of the purpose of the article. The aim of the article will be to identify the informational prerequisites for integration the pop culture into influencer marketing tools, thereby determining the relevance of this approach.

Statement of the main material of the research with full justification of the scientific results obtained. Franchises with the status of a global (or even international) level are faced with the need to make changes in marketing, and, accordingly, the management of the organization for effective commercial activity in certain markets. Sometimes it affects product design (in a broad sense), but in most cases it manifests itself in the system of integrated marketing communications. Mass product customization processes generate the need for customization marketing approaches also. The definition of culture goes hand in hand with marketing. According to the Cambridge Dictionary, culture is defined as the way of life, especially the general customs and beliefs, of a particular group of people at a particular time [11]. In the context of defining business strategies, culture manifests itself in the accumulation of user experience. The international standard for the ergonomics of human-system interaction, ISO 9241-210, defines user experience as human perception and reactions that arise as a result of the use or expected use of a product, system or service [12]. However, it is not possible to 
separate the user experience from the user's external infofield. The informational ecosystem leaves it's mark on the ability of the consumer to shape the user experience. In other words, the culture of a social group serves as a prism through which the interaction between the brand and the consumer takes place, thereby, on the one hand, adding new restrictions to marketing strategies, and on the other hand, determining the vector of marketing communications.

Understanding this phenomenon will avoid the potential negative consequences of brand informational impact. However, this does not solve the problem of communication with the consumer due to the oversaturation of informational platforms by content. The characteristic of the "cultureness" of marketing tools requires an additional forcing component - virality.

The viral marketing effect, which manifests itself in additional points of contact of consumers with commercial content due to dissemination of it by the consumers themselves, can be achieved by integrating influencer marketing tools into the IMC system. In our early works, we proved that not only an opinion leader (person) can act as an influencer, but also absolutely any phenomenon. And the transition from competence to virality (popularity), as the main principle for identifying an influencer, turns a marketing strategy into a dynamic phenomenon with an increased level of flexibility compared to the traditional concept of influencer marketing, where the influencer is an opinion leader.

Consequently, the integration of social manifestations, which are characterized by "popularity" and "cultureness" simultaneously, seems to be a logical evolution of the concept of influencer marketing. This hypothesis is confirmed by empirical data obtained from the analysis of Google Chrome search queries and the use of thematic hashtags on the Twitter social network [13].

The improvement of information technologies used in the integrated marketing communications system is currently the main driving force of the reengineering of communication channels. This allows the idea of using the pop culture as an influencer marketing tool to be realized.

The usual IMC concept, which can be considered in the complex impact of 4P (product, price, place, promotion) for the commodity business and 7P (+ people, physical evidence, process) for the service business has been transformed due to the development of information technologies and their introduction into the marketing management system and marketing communication. Goods and services that at first glance are not related to the IT sphere (food, tourism, fashion, etc.) acquire integrated informational components that produce a behavioral residue among consumers. It can be a QR-code on the wrapper of a chocolate bar, hashtags with the names of points of interest in social networks, or even tattoos depicting soundtracks that can be played on a smartphone.

Thus, considering the brand's products as a channel of communication with the consumer, it becomes possible to integrate influencer marketing tools at the stage of product functionality design or making decisions about it's appearance (shape, color, size, etc.). Clothing brands act as a particular ambassador for this approach, entering into collaboration with influencers from the world of the pop culture. A prime example is the Adidas sneakers from Stark Industries. The use of the pop culture in this case is obvious (Stark Industries is a fictional multi-billion dollar corporation from the Marvel comics Universe). The role of the first influencer as an opinion leader namely a fictional character (Tony Stark) is unusual for the outdated paradigm of influencer marketing. The second influencer will be a product of Marvel Entertainment - comics. Due to the high level of popularity of Marvel comics, their integration into brand products is scalable in both quantitative and qualitative terms. This is not only an increase in the number of models of Marvel sneakers, but also completely different markets 
with different products. Marvel was used as an influencer by American beauty salon chain Ultra Beauty, shaving accessories brand Gillette and many others.

The example, at the same time associated with the informatization of manufactured products and the integration of the pop culture in the Ukrainian market, is the New Year's collaboration between the producer of non-alcoholic carbonated drinks "Coca-cola" and the Ukrainian hip-hop artist Monatik. After scanning the QR-code on a can with a drink a video was played on a smartphone with a remix of the cult New Year's song "Holiday is coming ". Thus, using not only an opinion leader as an influencer, but also a New Year's melody. Both influencers have characteristics of "popularity" (recognition, viral effect) and "cultureness" (integration into the way of life).

A similar situation is observed in price-creating instruments. Taxi services use software crawlers to parse information from weather or traffic congestion services to determine the cost ratio of a trip. Another example is the implementation of calculators for determining the price on the website or in the application of an enterprise (renovation, vehicle equipment, post, etc.).

The communicative function of the pricing policy has manifested itself in the light of the current trend, according to which consumers can on their own offer the price they are willing to pay. This approach to price formation can be considered on a par with the existing ones (BCG matrix, price discrimination, etc.). Information services based on the technology of crowdfunding platforms allow not only to track changes in the value of brand products for the consumer, but also allow consumer to influence on the pricing policy. One of the first such services, which continues to function today, was the Patreon website. The prototype for the use of this approach was precisely the sphere of the pop culture. Patreon is widely used as a content monetization tool for video blogging, audio podcasts, copywriting, and other pop cultural or pop culture-related activities. Today we can observe the concept of determining the value of a provided service or product by users in areas not related to pop culture (transportation, contextual advertising, etc.), however, influencer marketing tools with integrated pop cultural manifestations have not lost their relevance and can be used to achieve the goal of increasing the value of the product or service being produced in the mind of the consumer.

The informatization of the "place" component began from the development of online stores, which went through several stages of evolution from a catalog site to Instagram accounts. The transformation continues in response to the development of IT and the demands of society. Virtual fitting rooms of clothes or makeup, quick dates in Tinder, food delivery and so on indicate changes in this "P", the vector of which is aimed at compactness and capacity. ITsimplified product access for consumers simplifies traditional distribution processes, eliminates the difference between downtown or dormitory area locations, and avoids unnecessary links involved in distribution channels.

There are many approaches used in managing consumer behavior on a store platform: locus management (focus of attention), cross-sale (offering related products), upsell (increasing sales with a lower cost per unit of product), optimizing checkout through autocomplete forms and so on. All tools of influence are determined by the level of usability of the online store, which is based on user experience. Therefore, the introduction of triggers that could have an impact on the target audience in the context of a specific infofield would be relevant.

One possible method for introducing such trigger into an interface is using fonts. Accents created by recognizable fonts can influence user behavior. Placement of accents in the description text inside the product card diagonally from the upper left corner to the lower right one (according to the rules of ergonomics) will be incorrect, since the main problem of modern commercial content is not keeping attention, but attracting it. Therefore, the use of pop-cultural fonts creating a design is appropriate in the headings of product cards or other layout elements, 
the purpose of which is to highlight and denote the subsequent block of information. Examples of existing fonts borrowed from the pop culture could be the following:

- the descender under the baseline of the font in the form of a lightning - the font of the names of the Harry Potter books (influencer is Harry Potter books and films);

- lopsided acute-angled font from the world of Cyberpunk gaming (influencer is a video game);

- SEGA logo font, the symbols of which are created by two parallel lines (influencer is a game console of the early 2000s), etc.

In addition to manipulating fonts, integrating pop cultural aspects is possible into any element of front-end development. On the websites of travel agencies, this is expressed in panoramic pop-cultural photographs (both traditional attractions and specific niche locations). However, the potential for pop cultural influencer marketing is much broader.

Benchmarking allows us to analyze, evaluate and compare existing business processes, but the use of this tool aiming to include potentially effective interface elements can extend to pop-cultural manifestations. The fixation of social manifestations with indicators of the pop culture occurs on the basis of marketing analysis, and after this the optimization or complete reengineering of the organization's distribution channel interface takes place in two stages:

1) Alpha testing, which occurs at the expense of the intellectual resources of the organization. Due to the informatization process, alpha testing methods used in the development of an IT product (smoke testing, regression testing, etc.) remain relevant.

2) Beta testing is attracting brand consumers and platform users for test process.

Promotion, as well as bordering categories (advertising strategies or sales stimulation strategies) is the most pictorial indicator of the informatization of marketing communications. For the problem indicated at the beginning of the article, as well as its intended solution, informatization and digitalization of tools for promoting a product or service is a basic prerequisite. Absolutely any product is promoted, including through IT. Preexisting exceptions (B2B products and service markets, high-value products, niche and unique products) have also crossed the threshold of entering the virtual world of content marketing and using digital platforms to communicate with the consumer.

Insofar as targeting has faced the attention problem of social media users the most, influencer marketing has become an integral part of content marketing. The tools used for "place" reengineering can also be used to transform targeting tools and promotion in general. The difference lies in the fact that in addition to endowing functional elements with pop-cultural characteristics, in promotion the integration of the pop culture is possible in the semantic load of the content. The target audience, as well as the views and values of consumers reflexed by the pop culture, will be a key component in choosing pop cultural expressions that will feature Easter eggs in the brand's content strategy.

The variety of forms of content, as well as their combination, allows us to use influencer marketing tools, taking into account the only limitation. It is creativity branding strategies. For example, let's take the pop-cultural phenomenon "STAR WARS" as an influencer, and video as the form of content.

The first case is the promotion of $360^{\circ}$ gadgets by Verizon. The content consumer can observe the space travel, galactic leap and The Death Star attack from the first person.

Another case is less specific. By integrating references to "STAR WARS" into the video, Duracell showed the power of children's imagination. All the heroes of the video, children, are in the hospital. They are carrying a toy robot R2-D2 as a present for the girl. As the children walk to her room, they imagine themselves as rebels onto a ship with stormtroopers. The marketing campaign of the brand was not targeted at consumers of niche products, which 
only emphasizes the versatility of influencer marketing tools with pop-cultural expressions integrated into them.

The next case is the promotion of the Nissan Rouge car. The automaker demonstrated a simulation of test-drive on the battlefield from "STAR WARS". The driver of the car dodges shots from robots, stormtroopers and rebels, and in the final slows down in front of the K-2SO droid. Thus, the company showed an obstacle detection system and emergency braking system.

In the context of integration of the pop culture into influencer marketing strategies, these cases make it clear that the described solution to the existing problem, namely high competition for the attention of consumers, is equally effective for both expensive and everyday household goods. The target audience of the brand is overlapping, however, it is not limited to the target audience of the pop cultural manifestation.

Demonstration of the human factor, staff behavior, interaction between employees, customers, employees and customers also acquired informational signs. The presence of communication scripts, behavior models and self-learning neural networks allows manipulating informational components, changing them under the pressure of the consumers' loss of attention. Only functionality in this matter is not enough for a long time, and with equally optimized conditions of business processes, the consumer will give preference to the one that most closely matches the concept of "culture" based on the user experience of a social group or a specific individual.

Let's analyze a case from the history of the Canadian branch of Samsung. A loyal consumer of the brand asked for Galaxy S3 phone, which at that time was supposed to go on sale soon. In a FB post on the page of the brand he listed the already purchased Samsungproducts, and to soften his request, he attached a digital drawing of a fire-breathing dragon. In response, Samsung Canada explained why they can not give away free phones, but to demonstrate the human factor, they complimented the dragon drawing and attached a digital drawing of the kangaroo to the unicycle. The user posted screenshots of this dialogue on one of the most popular sites in the world (ranked \# 19 by Alexa Internet Traffic [14]) Reddit. The post went viral, quickly gaining popularity, and the openness of the KPIs allowed the Samsung to measure audience reach of the post. Thanks to the original actions of technical support of the brand in the digital environment (informatization "P"), a behavioral residue was provoked. Because of the assessment of it's effectiveness, the Canadian still received a free smartphone. A bonus was design of it. On the back there was a drawing by the author - a fire-breathing dragon. In this case, the site Reddit was the influencer. Due to the combination of the features of a social network and a forum where posts can be discussed, rated and raised to the top, as well as its popularity and integration into the everyday social life of people, the effect of using this pop-cultural phenomenon for the brand turned out to be more valuable than the cost of a smartphone.

Thus, the "people" component can be used as a channel for communication in the digital space, and it is also possible to integrate marketing influencers into it.

Artifacts of physical evidence, in spite of the semantic meaning of this phrase, have also been transformed under the impact of information technology. The main material element of catering establishments (menu) in most cases has a digital analogue, which can be accessed by entering a link or scanning a QR-code. Tourism business artifacts (tickets, photos, excursion materials, etc.) have also been transformed due to the availability of applications and the capabilities of information services. This phenomenon is a response to the need of users to save time and space, which opens up opportunities for the introduction of marketing tools.

Consider an example from the banking industry. The existence of Internet banking is a logical stage in the implementation of informatization processes. Today in society, the issue of ecology, which in itself is a significant pop-cultural influencer, is acute. This aspect is widely 
reported in a number of pop cultural expressions, and the idea of sustainability is supported by many opinion leaders. In an effort to reduce the use of plastic, banks have started issuing digital credit cards. Thus, the physical artifact received a virtual analogue. However, the pop culture is not only the reason for this transformation, but also it is the consequence - because changing the design of a digital card is much easier than a plastic one. The idea of depicting pop cultural characters, video game or movie posters and other pop cultural expressions that was previously available to a select few is now available to everyone in just a few clicks. The customization of the artifact of physical evidence, and, accordingly, the customization of the interaction between the brand and the consumer, is a direct consequence of the introduction of influencer marketing tools.

The highest level of informatization corresponds to the last component of marketingmix which is "process". The development of diagrams and models, classification, standardization, diagnostics, monitoring, analysis, as well as performance indicators (KPIs) have completely turned from operational to informational processes. As with the previous components of the IMC, this allows the implementation of influencer marketing tools, but the need to do this within the "process" is not obvious. Nevertheless, the experience of consumer participation in the business processes of the enterprise, from product design to changes in the management structure or marketing strategy, not only positively affects the image of the organization, but also optimizes business processes for market demands.

The forecasting process, which closely interacts with another management function of planning, is often based on statistical data and an assessment of the user experience of interacting with the products of brand. User experience assessment is a flawlessly correct concept. An exception will be the innovative management function. Users lack the experience of interacting with the innovation due to the innovativeness of the product or idea. That is why the stages of alpha and beta testing are going after the analysis. One of the tools that simplifies this process is dialogue with consumers.

In the 2000s, industry hegemons like Starbucks and DELL launched a trend of gathering consumer ideas. Then specialized sites were created (today this can be done using not only sites, but also social networks, applications, interactive screens, etc.), on which brand consumers were able to offer an idea for optimizing a product or service. Companies have been able to get innovative ideas that correspond the needs of consumers, based on their own ideas. One of the ideas on the Starbucks website was a free wi-fi hotspot.

Since the ideas proposed on such communication platforms are aimed at optimizing the way of life, and the repetition of similar sentences allows brand to determine their popularity, this tool makes it possible to introduce pop cultural manifestations that are different from the generally accepted trivial definition of the pop culture. Rebranding of a company with reengineering of business processes is a response to the public mood, actual values and needs, the reflex of which is the goal of the modern pop culture.

Conclusions from this research and prospects for further developments in this area. Noting a certain deficit of compromise in time calculations and quality of results (accuracy - closeness of the value of the objective function to the global optimum, stability closeness of the obtained values to each other at iterative starts of the algorithm), the aim of this study segmentation of the company's customers, which would meet the following criteria:

- tasks must be solved in a reasonable time;

- to carry out automatic segmentation of a large number of objects in the multidimensional space of characteristics (dimension - tens of measurements);

- solve problems using different clustering models;

- combine with local search methods used to solve specific tasks, provide the 
opportunity to use different global search strategies;

- give stable results with multiple launches (be deterministic), while the accuracy of the results should not be inferior to other known methods;

- must either estimate the number of groups (segments), or solve a series of problems with different numbers of groups.

The choice of genetic algorithm as a means of market segmentation is due to the fact that these methods allow to obtain high-precision results, characterized by deterministic procedures, which gives hope for more stable results when using such heuristics in various global search strategies, including marketing research.

1. Selivanova D.I. (2020) Sovremennaya massovaya kul'tura i ee vliyanie na cheloveka [Modern mass culture and its influence on man]. Questions of science and education, vol. 1, no. 85, pp. 99-103.Petrov I.F. (2019) Smysl massovoy kul'tury [The meaning of mass culture]. The science, vol. 7, no. 32, pp. 194-200.

2. Drabchuk Y.P. (2013) Pop-kuljtura i jiji vplyv na ljudsjku svidomistj [Pop culture and its impact on human consciousness]. Bulletin of the Mariupol State University, vol. 6, no. 8, pp. 33-38.

3. JD Tjaden, C. Schwemmer, M. Khadjavi (2018) Ride with me -Ethnic discrimination, social markets, and the sharing economy. European Sociological Review, vol. 34, no. 4, pp. 418-432.

4. D. Fischer-Preßler, C. Schwemmer, K. Fischbach (2019) Collective sense-making in times of crisis: Connecting terror management theory with Twitter user reactions to the Berlin terrorist attack. Computers in Human Behavior, vol. 100, 138-151.

5. D. Carter (2016) Hustle and Brand: The Sociotechnical Shaping of Influence. Social Media + Society, vol. 2, no. 3, pp. 1-12.

6. S. Bishop (2021) Influencer Management Tools: Algorithmic Cultures, Brand Safety, and Bias. Social Media + Society, vol. 7, no. 1, pp. 1-13.

7. Tulchinsky G.L. (2006) Marketing i massovaya kul'tura [Marketing and popular culture]. Bulletin of culture and arts, vol. 2, no. 10, pp. 54-66.

8. Gritsyuk Y.S. (2020) Osobennosti prodvizheniya innovatsionnogo produkta: inflyuensery kak vazhneyshiy kanal kommunikatsiy [Features of promoting an innovative product: influencers as the most important communication channel]. StudNet, vol. 3, no. 9, pp. 1094-1100.

9. Popova O.I., Timokhina G.S., Nesterova Z.V. (2017) Vliyanie kul'turnykh fenomenov globalizatsii na povedenie sotsial'no-ekonomicheskikh sub"ektov mirovykh rynkov [The influence of cultural phenomena of globalization on the behavior of socio-economic subjects of world markets]. Proceedings of higher educational institutions. Sociology. Economy. Politics, vol. 4, pp. 55-60.

10. Culture. Cambridge dictionary. URL: https://dictionary.cambridge.org (date of application: 09/26/2021).

11. Ergonomics of human-system interaction. ISO. URL: https://www.iso.org (date of application: 09/26/2021).

12. Chaikovska M.P., Shkeda O.O. (2021) The role of the pop-cultural phenomenon in the management of the reflexive tools of modern influencer marketing strategies in the context of digitalization. Innovation economic development institutional and organizational dimension. Comrat: Minutes, pp. 156-176.

13. Competitive Analysis, Marketing Mix and Traffic. Alexa. URL: https://www.alexa.com (date of application: 09/26/2021).

Чайковська М.П., канд. екон. наук, доцент, доиент кафедри маркетингу та бізнесадміністрування, Одеський національний університет імені I.I. Мечникова (Одеса, Украӥна).

Шкеда О.О., аспірант, викладач, Одеський національний університет імені I.I. Мечникова (Одеса, Украӥна).

Реінжиніринг комунікацій бренду зі споживачем через інтеграцію поп-культурних інструментів маркетингу впливу у традиційні маркетингові компоненти. 
Стаття присвячена процесам трансформачії маркетингових комунікацій в умовах інформатизаиії та діджіталізачіi суспільства. Розглянуто проблему перенасичення інформаційних платформ контентом. В якості вирімення запропоновано використовувати інструменти маркетингу впливу з інтегрованими проявами поп-культури. Виявлено інформачійні передумови використання даного підходу. Описана трансформація компонентів маркетингу-тіх, а також наведені приклади і розібрані кейси використання пропонованого методу вирішення існуючої проблеми для кожного з компонентів. Сформульовано принципи інтеграції поп-культурних інструментів маркетингу впливу для кожного з компонентів маркетингу-тіх. Обумовлена релевантність реінжинірингу комунікаиій бренду зі споживачем шляхом інтеграції поп-культурних інструментів маркетингу впливу в компоненти традиційного маркетингу.

Ключові слова: управління маркетингом, інтегровані маркетингові комунікації, побудова бренду, реінжиніринг, маркетинг впливу, 4Р, 7Р, інформатизація, діджиталізація, поп-культура.

Received to the editor 15 March, 2021. 